\title{
Lakes sensitivity to climatic stress - a sociological assessment
}

\begin{abstract}
One of the conditions for effective water resources management in protected areas is local decision makers' knowledge about potential threats caused by climate changes. Our study, conducted in the UNESCO Biosphere Reserve of Tuchola Forest in Poland, analyses the perception of threats by local stakeholders. Their assessments of the sensitivity of four lakes to the extreme weather events are compared with hydrological studies. The survey shows that the lakes' varying responses to extreme weather conditions is rarely noticed by ordinary observers. Their perception is usually far from the hydrological facts, which indicates a lack of relevant information or a failure in making it widely accessible and understandable. Moreover, it is rather the human impact, not climate change, which is seen as the biggest threat to the lakes. Insufficient environmental knowledge may hinder the effective protection and management of natural resources, due to bad decisions and lack of the local communities' support for adaptation and mitigation policies.
\end{abstract}

Keywords

Climate changes $\cdot$ human impact $\cdot$ lake hydrological sensitivity $\cdot$ threats perception $\cdot$ natural resources management

(C) University of Warsaw - Faculty of Geography and Regional Studies

Introduction

World reports (IPCC 2007, 2012) analysing future climate changes as an effect of global warming, present them as a "crucial environmental, social and economic problem" (Wpływ zmian klimatu... 2012). The expected climate changes will result in the intensification of extreme (hazardous) weather events that go beyond daily experience (Nowicka 2009); such as heat waves and long periods of atmospheric drought followed by torrential rain causing floods in other periods. This is expected to negatively influence the quality and quantity of water resources, and not only in areas where there is a water deficit. This is proven by the results of studies done on European lakes and carried out within research projects like CLIME 2007-2010 (George 2010) and EULAKES 2010-2013 (Kutics 2012; Nowicka et al. 2012; Soja et al. 2012; Sighel 2012).

The effects of climate changes (i.e. the increase of the number of extreme weather and hydrological events) have an influence at the local level, making local governance crucial in both the mitigation of these changes and in adapting to their local consequences (Shaw and Theobald 2011; Hoppe et al. 2014). A vast body of literature acknowledges and analyses the way in which local communities undertake policies in the face of climate change and its impact on localities (Bulkeley and Kern 2006; Granberg and Elander 2007; Storbjörk 2007; Jackson and Lynch 2011; Shaw and Theobald 2011; Hoppe et al. 2014, Szmigiel-Rawska 2016). It has been proved that the willingness to undertake climate policies at the municipal level depends on having experienced extreme weather events in the
Marta Lackowska', Barbara Nowicka ${ }^{2,3}$, Marta Bałandin ${ }^{2}$, Mirosław Grochowski ${ }^{4}$

'Department of Local Development and Policy, Faculty of Geography and Regional Studies, University of Warsaw

e-mail:m.lackowska@uw.edu.pl

${ }^{2}$ Centre for General Hydrological Services, Institute of Meteorology and Water Management National Research Institute (IMGW-PIB) e-mail: barbara.nowicka@imgw.pl; benowick@uw.edu.pl e-mail: marta.balandin@imgw.pl

${ }^{3}$ Department of Hydrology, Faculty of Geography and Regional Studies, University of Warsaw e-mail: barbara.nowicka@imgw.pl; benowick@uw.edu.pl

${ }^{4}$ Department of Urban Geography and Spatial Organization, Faculty of Geography and Regional Studies, University of Warsaw e-mail:m.grochowski@uw.edu.pl

Received: 4 February 2016 Accepted: 2 November 2016

past (Lackowska and Swianiewicz 2016; Gendźwił 2016). As a result, the perception of unfavourable events becomes an important factor for appropriate local policies. If the local community is not convinced of the threat, it may be difficult for local authorities to justify adaptation and mitigation policies.

Apart from the perception of past threats, there are also other factors influencing the effective management of environmental issues. One of them is connected with learning (Orderud and Windsvold 2012). Knowledge about environmental conditions and the possible means for carrying out the mitigation of and adaptation to climate changes is crucial to undertaking action. Consequently, providing the various groups of local stakeholders with information about the current status of resources and threats becomes crucial to motivating them to work towards the protection and sustainable use of natural resources (Grimble and Wellard 1997; Varvasovszky and Brugha 2000; Reed et al. 2009; Romanelli et al. 2011). Information dissemination should be broad as there is no single group of decision-makers responsible for environmental management (Eckerberg and Joas 2004; Lempert et al. 2004): local governance processes (John 2001; Mazur 2015) include a wide range of actors from the public and private sector, as well as the civil society sector. The effective flow of information may influence policy making by changing the approach of stakeholders to environmental issues in general (Axelrod and Lehman 1993): it can contribute to, for example, the choice of specific measures and instruments of policy implementation, and the approval of 
related restrictions. It also facilitates the democratic legitimization of local climate policies. Such policies should be acknowledged by inhabitants in order to minimize antagonisms, frustrations, delays and expenditures in the efforts of hazard management (Slovic et al. 1982). In this way the development of socially acceptable risk management plans and policies can be achieved (Tierney et al. 2001).

Communication about environmental threats can be used as a tool to provide information, to explain and warn, and to encourage collective partnership approaches to decision-making through greater public participation in the threat management process (Calow 1998; Gondo 2011). Effective communication is affected by several variables that influence the subjective picture of potential environmental threats (perception of threats), such as sources of information (other people, mass media) or knowledge acquired at different stages of education and professional life. The exchange of knowledge is combined with personal experience and previous observations.

Moreover, many of the meteorological consequences of climate change, such as the long-term effects of meteorological impact on the water resources of lakes, are very moderate and thus difficult to perceive by local users of environmental resources. This is very different from the case of severe hazards, like hurricanes, floods, and water pollution; which are spectacular and easily visible (Langford et al. 2000; Wong and Zhao 2001; Lindell and Prater 2002; Peacock et al. 2005).

The analysis of, and response to, local environment data is not an easy task - climate change is a "wicked problem" (Hanssen et al. 2013) that is associated with great uncertainty. In this context, the flow of information between scientists and those responsible for local governance appears to be particularly important (Sulzmann et al. 1995; Schröter 2005; EEA 2008; Biesbröek et al. 2009; Feldman and Ingram 2009; Johnson and Weaver 2009; Rannow et al. 2010; Lynch 2011; IPCC 2012). This dialogue between different stakeholders is not only often difficult and not productive enough due to communication problems and each persons own "observation filter" (see e.g. Johnson and Weaver 2009; Rannow et al. 2010; Carmi and Bartal 2014), but also difficult as the topic itself is scientifically challenging.

All these elements contribute to the importance of knowledge on natural resources possessed by local actors and the complexity of information flows in effective local management of environmental issues.

\section{Research outline}

In this paper the authors rely on the findings from their other project, Polcitclim - Organizing for resilience. A comparative study on institutional capacity, governance, and climate change adaptation in Poland and Norway, funded by Norway Grants under the Polish-Norwegian Research Programme operated by the National Centre for Research and Development (contract no POL-NOR/201304/75/2013). Our survey proved that the perception of future threats is affected by the observation of current responses of the local environment to extreme weather conditions (Lackowska, Swianiewicz 2016, Gendźwiłł 2016). We therefore investigated the perception of contemporary lake conditions, their changes and their vulnerability to various meteorological threats, as this perception is decisive for the undertaking of future adaptation and mitigation policies.

The main research question is about the state of the knowledge among local stakeholders. In particular:

1. Does the assessment by the local community towards the lakes correspond to hydrological findings? Do the respondents see the same threats as the scientists do? Do they notice the differences in the hydrological status of the lakes under study?
2. Do the respondents see the relationship between changes in water resources of the lakes and weather conditions?

3. Do the respondents differ significantly in relation to the above mentioned issues?

4. What are the main sources of the respondents' knowledge?

The authors have formulated two main propositions. The first hypothesis $(\mathrm{H} 1)$ is that the current low hydrological sensitivity of a lake causes a poor perception of the risk. This in turn can demotivate the community in implementing the protective measures and adaptation policies. Moreover, the authors assume that despite a general Poland-wide information campaign and numerous public documents, climate impact is still not being considered by local actors as a factor that influences local conditions (or, more precisely, had not been considered as such at the time we conducted our study). Therefore we expect, that $(\mathrm{H} 2)$ climate changes and their impacts on lakes (in the form of meteorological events) are overlooked by local stakeholders. This assumption is also based on the fact that in the area chosen for the study throughout last two decades there has been no extreme weather events that could easily be linked to climate change in the public perception. Meteorological conditions subject lakes to a more moderate influence, which is more difficult to notice and subscribe to the influence of climate change than, for instance, the case of rivers prone to flooding. This hypothesis has a sub-proposition $(\mathrm{H} 2 \mathrm{a})$, in which the authors assume that more educated groups notice the impact of climate on local lakes more frequently than less educated respondents (in general their opinions should be more coherent with hydrological knowledge).

To verify these hypothesis, the authors have carried out research on the local communities and governments' perception of the state of, and threats to, four ribbon lakes located in the Tuchola Forest Biosphere Reserve in Poland. The results of sociological analysis were compared to the hydrological analysis conducted by the University of Warsaw (Nowicka and Lenartowicz 2004, Nowicka 2006) and the Institute of Meteorology and Water Management - NRI within the EULAKES Project (Nowicka et al. 2012, Nowicka and Bałandin 2012, Nowicka et al. 2016).

The study area is located in the South Baltic Lake District. The largest lake, Charzykowskie Lake (13 $\mathrm{km}^{2}$ area), is a flowthrough water body with a large catchment area $\left(920 \mathrm{~km}^{2}\right)$. A disturbance in water resources in the drainage basin will affect the status of Charzykowskie Lake. Even at present, shortages in the municipal water supply occur in the upper catchment of the lake and additional sources of supply are being searched for. This problem will increase along with the projected climate changes. At present, Charzykowskie Lake still stores a large quantity of water resources. The changes in water level between 1950 and 2010 did not exceed one meter, yet did not cause significant changes to the lake's area. The lake is of great importance for recreation, water sports, and nature tourism, and as such is subjected to increasing human influence. It serves as a weekend base for the town of Chojnice with 40,000 inhabitants, the urban sprawl of which expands in the direction of the lake. The water and sewage management of Chojnice, as well as the inflow of nutrients from distant agricultural areas, affect the eutrophication of the lake.

Three neighbouring lakes were selected for comparative analysis. They are located in the Tuchola Forest National Park near Charzykowskie Lake. These are: two closed lakes - Małe Gacno and Wielkie Gacno, and the third is the outflow Ostrowite Lake. The location in the National Park ensures the legal protection of all natural objects, including the lakes. Only Ostrowite Lake is available, but only to a limited number of anglers. All three lakes show very good ecological statuses and were not subject to long-standing directional changes in ecological status 
(Zdanowski et. al. 2004). However, they are sensitive to extreme weather events. This applies in particular to the closed lakes located in the forest.

The lakes selected for the studies all experience the same exposure to climatic conditions but have different sensitivities to extreme weather events, as well as different ecological statuses. In particular, the area's lakes and their response time to shortages and surpluses of water that are supplied to the lakes as a result of atmospheric exchange (precipitation, evaporation) are different. In Charzykowskie Lake, the most resilient of the lakes, delays reach 12 months or even longer. In contrast, for the more sensitive, closed lakes (Gacno Lakes and Ostrowite Lake) reactions are synchronized with changes in the conditions of atmospheric exchange. The effects of water shortages are quickly visible. These differences between the lakes were strengthened during the 1990s, mainly due to severe droughts, whereas, ten years later, we observed big differences in the rebuilding of water resources caused by increased precipitation (Nowicka and Lenartowicz 2004, Nowicka 2006).

At the same time the protected, sensitive lakes are characterized by a very good ecological state (high water transparency, valuable species of plants, good oxygen conditions), whereas the hydrologically resistant Charzykowskie Lake has a moderate ecological state (poor water transparency, loss of valuable fish species and the displacement of valuable plant species, and also blooms appearing lowering attractiveness of the lake).

The protection of Charzykowskie Lake depends on actions taken within its large catchment area $\left(920 \mathrm{~km}^{2}\right)$, and thus requires the conviction of a large group of stakeholders in protective action. The disturbance of the water resources in the drainage basin will affect the status of Charzykowskie Lake. Another issue is the need to reduce nutrient inflow. This problem will increase together with the foreseen climate changes. Therefore, analysis at the local level and, at the same time, the dissemination of information to the local community and among decision-makers is very important for proper risk management.

Various forms of educational activities have been conducted that relate to the ecological state and protection of all the lakes studied. Several very active NGOs are involved in these activities. Many activities are addressed to young people of school age. Classes are often held by the lakes (for instance, on Charzykowskie Lake there is an educational ship). During these, and numerous other local workshops, the main problem discussed is the need for protection against human pressure. Meanwhile, the theme of predicted risks in climate change began to be discussed at the local meetings within the EULAKES Project in 2013. Among the participants there were representatives of local governments and municipalities, press, environmental protection agencies, NGOs, and teachers.

The sociological part of the research - threat perception was based on a survey conducted in the second half of 2013 and first half of 2014. The questionnaire used in the study consisted of three main parts: (1) questions about the current status of the lakes, changes in their conditions (trends of change) and the main factors affecting these conditions; (2) assessment of the threats due to climate change, and (3) questions about resources of information about the lakes.

A total of 4,500 questionnaires were distributed via traditional post, personally or via e-mail, taking into account the size of the total population and the spatial distribution of the groups of stakeholders.

The authors decided to focus on two groups of local actors (Table 1). The first group is composed of five types of professionals with a direct or indirect impact on the management of the lakes and the formation of attitudes towards environmental
Table 1. Characteristics of research sample (number of respondents from distinguished groups; only 2,514 questionnaires with full sets of answers are included)

\begin{tabular}{|l|c|c|c|}
\hline & $\begin{array}{c}\text { Municipalities } \\
\text { adjacent to the } \\
\text { Tuchola Forest } \\
\text { National Park* }\end{array}$ & $\begin{array}{c}\text { Further } \\
\text { municipalities }\end{array}$ & $\begin{array}{c}\text { Locations not } \\
\text { in the region** }\end{array}$ \\
\hline $\begin{array}{l}\text { Pupils \& } \\
\text { students }\end{array}$ & 1239 & 601 & 32 \\
\hline Activists & 539 & 87 & 16 \\
\hline
\end{tabular}

*Chojnice, Brusy, Człuchów

**This group was excluded from the analysis because of its small number.

protection. This group represented $25 \%$ of the total sample, and comprised: representatives of the public authorities (local and regional governments), environmental protection services, teachers, and representatives of non-governmental organizations (NGOs). In most of the analysis all these professions are treated as one "activist group" for two reasons. First, splitting the group by professions does not ensure statistical significance, as the resultant groups are too small for statistical testing. Second, all these professions are united by their specific position in local society (engagement in local governance, and/or creation of local discourse) and the possession of professionally related, specific knowledge on natural environmental issues. The questionnaires were sent either directly to the persons dealing with environmental issues, or (in big institutions) to a main contact person with a request to pass the questionnaires on to the relevant people (a snow-ball method with one round).

The second group gathered together pupils and students ( $75 \%$ of the respondents). This is an important group, who are current and future users of the lakes, and who have direct and easy access to information and knowledge about natural environmental issues. The survey was distributed in all the schools in Chojnice county, as well as in other selected schools where courses on the National Park were held, and so a higher level of knowledge was expected.

The disproportionate numbers between the two groups reflects the proportions in the whole population, where there are many more pupils and students than professionals and activists interested in environmental issues. Moreover, the disproportionate numbers are also linked, to some extent, to the difference in willingness to answer the questions, which partly stems from the method of gathering questionnaires. Pupils were asked by their teachers to fill in the questionnaire during classes. This method, carrying elements of hierarchy, resulted in a very high response rate (ca $84 \%$ ). In the case of activists, no element of hierarchical reinforcement was used, which led to a relatively low turn-out of ca. $37 \%$.

A total of 2,674 completed questionnaires were received (giving an overall response rate of $60 \%$ ), which ensured the results were representative of the respondents from municipalities located in the immediate vicinity of Charzykowskie Lake. It should be noted that most of the respondents who showed an interest in the research were residents of municipalities in the nearest vicinity of the lakes $(71 \%$ of answers came from three municipalities adjacent to the Tuchola Forest National Park). Answers were provided by the representatives of the environmental services at the regional level (specialized agencies dealing with environmental problems from the regional perspective and actively involved in supra-local and nationwide programs) and by National Parks' 
representatives, who are directly accountable to the central government. Few answers came from the representatives of local governments of municipalities located away from the lakes. This situation is diagnostic: the perceived importance of the lakes' ecological condition and threats to the lakes, declines with distance from the lakes. At the same time, both conditions and threats also depend on the development processes and the ways in which the environment is being used in municipalities located far away from the lakes, yet belonging to the same water basin.

For the purpose of the analysis, the sample was divided into groups based on: (1) the place of residence (three municipalities adjacent to the National Park: Chojnice, Brusy and Człuchów, see map - Fig. 1 and Tab. 1); versus further municipalities located up to $\mathrm{ca}$. $100 \mathrm{~km}$ from the lakes studied; (2) affiliation with a group of pupils or students, or with a group of "activists" who influence attitudes and provide knowledge about the environment; (3) the type of respondent: 1 - pupil, 2 - student, 3 - representatives of local, county and regional government, 4 - teachers and trainers, workers from National Parks and Landscape Parks, journalists, NGOs dealing with environmental protection, 5 - qualified users of the lakes (representatives of the tourist industry, fishery, forestry); (4) the age of respondents. Subsequent topics were analysed using contingency tables (categorisation referred to the groups described above). Differences between the groups were checked either with "t" test (for samples divided into 2 subgroups) or ANOVA if the sample was split into numerous groups). The data was analysed using SPSS 21 software.

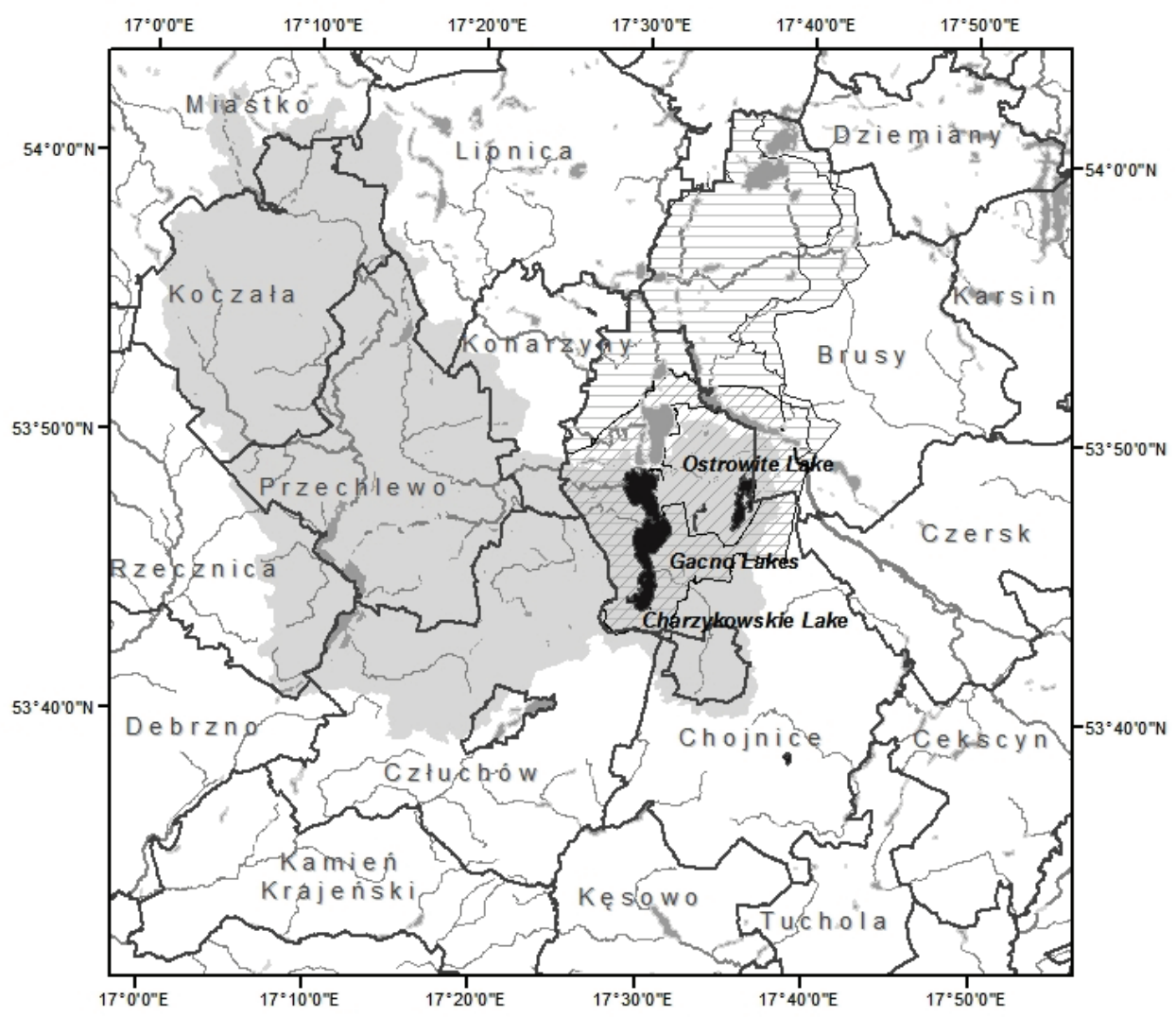

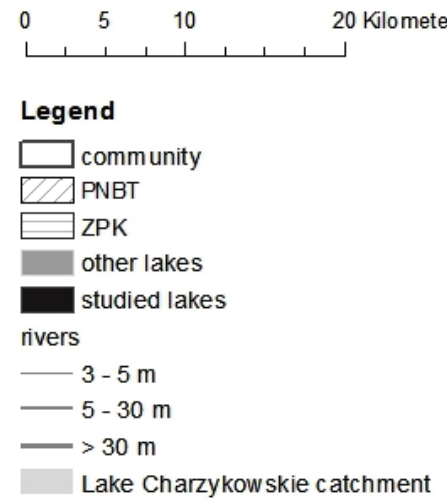

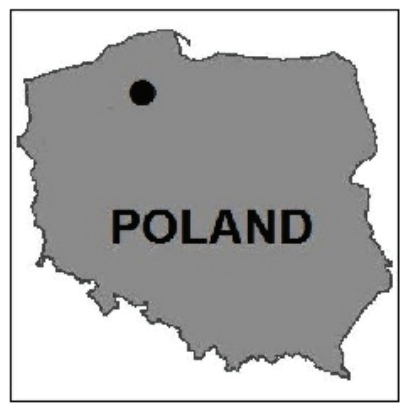

Figure 1. The location of residence of questioned groups 


\section{Perception of the lakes' sensitivity}

Two elements were included in the sociological analysis as an indication of perceived sensitivity: (1) the general assessment of the lakes' condition (Table 2 and 3) and (2) the assessment of the threats to which the lakes are exposed (Table 4). Charzykowskie Lake is always perceived as the one with the worst status (Fig.2), which is in accordance with scientific findings about its ecological status. Respondents also see Charzykowskie as the one most exposed to various threats (Table 4), which contradicts hydrological findings that it has a low sensitivity to weather conditions.

When it comes to the perception of changes, the situation is more complicated. People see Charzykowskie Lake as having the most dynamic changes in the direction of deterioration (Fig. 3, Table 3), whereas in reality Charzykowskie Lake is (1) the least vulnerable of all the lakes investigated (with the smallest changes resulting from meteorological conditions), and (2) its ecological conditions have recently improved. Moreover, people tend to notice only threats and changes related to human pressure and neglect the influence of climate, which is also a mistake. The lakes located in the National Park are perceived as being rather stable, with only minor changes occurring $(50 \%$ or more of responses, Fig. 3, Table 3 ), whereas hydrological studies proved they are very sensitive to meteorological conditions. In general one can say that the respondents' knowledge seems to be rather intuitive and not very well based on science.

The differences between the groups in the assessment of the lakes' condition is statistically significant ("t" test); nonetheless, they show no clear pattern. When looking at the place of the residence, it appears that respondents living in the vicinity of the lakes assess the lakes in the National Park better than the respondents from more distant locations. They also perceive Charzykowskie Lake as being much worse than residents from municipalities further away. The most evident differences (" $t$ " test) were obtained when dividing the group into students and activists. The evaluation is always more positive among the latter compared to the students and pupils (Table 2).

For the assessment on the changes in the lakes' condition, differences between the various groups of respondents are statistically relevant only for Charzykowskie Lake and partly for the Gacno lakes (Table 3). Changes are observed much more often among people living close to the lakes (the difference is significant only for Charzykowskie, but we cannot ignore

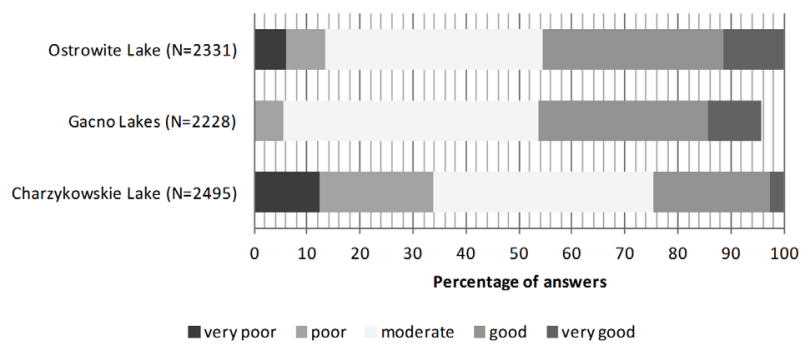

Figure 2. The general assessment of the condition of the studied lakes

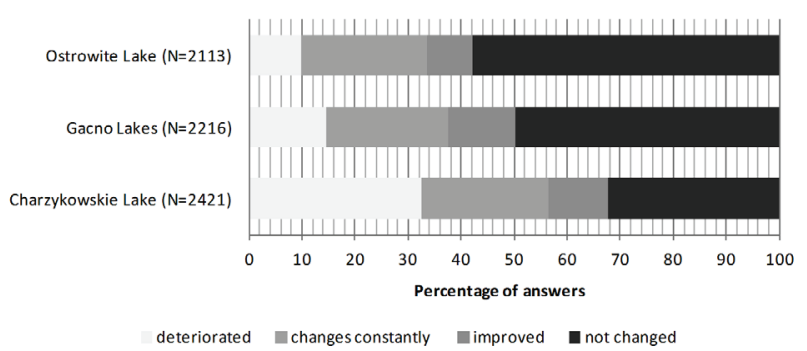

Figure 3. The perception of changes in the lakes' condition

Table 2. The average score for the general assessment of the conditions in the lakes studied (scale of answers 1-4, where 1 means "very poor" and 4 "very good")

\begin{tabular}{|c|c|c|c|c|c|c|c|}
\hline Lake & $\begin{array}{c}\text { Average } \\
\text { for the whole } \\
\text { sample }\end{array}$ & $\begin{array}{c}\text { Average } \\
\text { for } \\
\text { students }\end{array}$ & $\begin{array}{c}\text { Average for } \\
\text { activists }\end{array}$ & $\begin{array}{c}\mathbf{P} \text { in } \\
\text { "t" test }\end{array}$ & $\begin{array}{c}\text { Average for } \\
\text { adjacent } \\
\text { municipalities }\end{array}$ & $\begin{array}{c}\text { Average for } \\
\text { further } \\
\text { municipalities }\end{array}$ & $\begin{array}{c}\mathbf{P} \text { in } \\
\text { "t" test }\end{array}$ \\
\hline $\begin{array}{c}\text { Charzykowskie } \\
\text { Lake }\end{array}$ & 2.81 & 2.74 & 2.99 & 0.000 & 2.70 & 3.11 & 0.000 \\
\hline Gacno Lakes* & 3.38 & 3.25 & 3.77 & 0.000 & 3.43 & 3.23 & 0.000 \\
\hline Ostrowite Lake & 3.37 & 3.27 & 3.65 & 0.000 & 3.38 & 3.32 & 0.151 \\
\hline
\end{tabular}

*Małe Gacno and Wielkie Gacno; Differences assumed statistically significant when in " $t$ " test for equality of means $p<0.05$.

Table 3. The percentage of respondents who observed changes in the condition of the lakes

\begin{tabular}{|c|c|c|c|c|}
\hline Lake & $\begin{array}{c}\text { Adjacent } \\
\text { municipalities }\end{array}$ & $\begin{array}{c}\text { Further } \\
\text { municipalities }\end{array}$ & Pupils and students & Activists \\
\hline Charzykowskie Lake & $\mathbf{7 0 . 0 6}(\mathrm{p}=\mathbf{0 . 0 0 1 )}$ & $\mathbf{5 9 . 7 3 ( p = 0 . 0 0 1 )}$ & $\mathbf{6 6 . 9 5}(\mathrm{p}=\mathbf{0 . 0 0 0})$ & $\mathbf{8 9 . 4 5}(\mathrm{p}=\mathbf{0 . 0 0 0 )}$ \\
\hline Gacno Lakes* & 40.51 & 45.26 & $\mathbf{4 0 . 5 1 ( p = 0 . 0 0 0 )}$ & $\mathbf{4 5 . 2 6}(\mathrm{p}=\mathbf{0 . 0 0 0 )}$ \\
\hline Ostrowite Lake & 47.56 & 57.55 & 52.02 & 44.4 \\
\hline
\end{tabular}

*Małe Gacno and Wielkie Gacno; Means in bold - differences are statistically significant (in the "t" test for equality of means, $p<0.05$ ) 
Table 4. Assessment of various threats posed to the lakes

\begin{tabular}{|c|c|c|c|c|c|c|}
\hline \multirow[b]{2}{*}{ Lake } & \multicolumn{5}{|c|}{ Average risk assessment for five investigated fields (1-5 scale $\left.{ }^{* *}\right)$} & \multirow{2}{*}{$\begin{array}{l}\text { "don't know" for } \\
\text { all five risks in the } \\
\text { whole sample }\end{array}$} \\
\hline & $\begin{array}{l}\text { In the whole } \\
\text { sample }\end{array}$ & $\begin{array}{c}\text { In adjacent } \\
\text { municipalities }\end{array}$ & $\begin{array}{c}\text { In further } \\
\text { municipalities }\end{array}$ & Activists & Pupils / students & \\
\hline Charzykowskie Lake & 2.73 & 2.80 & 2.51 & 2.88 & 2.68 & 24.4 \\
\hline Gacno Lakes* & 2.41 & 2.43 & 2.35 & 2.44 & 2.40 & 48.8 \\
\hline Ostrowite Lake & 2.42 & 2.43 & 2.42 & 2.46 & 2.41 & 32.4 \\
\hline
\end{tabular}

*Małe Gacno and Wielkie Gacno; ** 1 meaning no risk at all, 5 meaning very high risk; the five investigated fields were: low water, high water, deterioration of water condition, sea line erosion, extinction of valuable fish species due to a raise of temperature and deterioration of oxygen conditions. Differences between the means statistically significant only for Charzykowskie Lake (in the " $t$ " test for equality of means $p=0.000$; for other lakes $p>0.05$ ).

Table 5. Which factors have the strongest influence on the status of the lakes? (\% of answers)

\begin{tabular}{|c|c|c|c|c|c|c|c|}
\hline & \multirow{2}{*}{$\begin{array}{c}\text { Charzykowskie } \\
\text { Lake }\end{array}$} & \multirow{2}{*}{$\begin{array}{l}\text { Gacno } \\
\text { Lakes* }\end{array}$} & \multirow{2}{*}{$\begin{array}{l}\text { Ostrowite } \\
\text { Lakes }\end{array}$} & \multicolumn{4}{|c|}{ Charzykowskie Lake** } \\
\hline & & & & Pupil/ student & Activists & $\begin{array}{c}\text { Adjacent } \\
\text { municipalities }\end{array}$ & $\begin{array}{c}\text { Further } \\
\text { municipalities }\end{array}$ \\
\hline $\begin{array}{l}\text { Meteorological } \\
\text { conditions }\end{array}$ & 9.71 & 19.77 & 19.91 & 11.13 & 6.41 & 8.62 & 13.02 \\
\hline \multirow[t]{2}{*}{ Human activity } & 50.83 & 34.49 & 36.09 & 51.47 & 52.27 & 52.64 & 46.27 \\
\hline & & & & \multicolumn{2}{|c|}{$p=0.035$} & \multicolumn{2}{|c|}{$p=0.024$} \\
\hline
\end{tabular}

"Małe Gacno and Wielkie Gacno; *'Differences between the groups are statistically significant only for Charzykowskie Lake (in "t" test $p<0.05)$.

that the same pattern occurs for other lakes). This remains in accordance with the fact that they seem to obtain their knowledge from their own observations rather than from other sources (see "Information" section). Even activists see changes in Charzykowskie Lake much more often than in the Gacno lakes (and more often than pupils). This indicated that they also take into consideration mainly ecological changes related to human activity, and not changes triggered by meteorological conditions.

Risk assessment - is it about climate at all?

The perceived condition of the lakes is also confirmed by the risk assessment (Table 4). Charzykowskie Lake is perceived as the most endangered, whereas the Gacno lakes and the Ostrowite Lake obtained similar but lower scores.

In general, the answers differed depending on the group of respondents, with activists noticing more differences between the lakes than students, and respondents from adjacent municipalities more than those living further away (this is true for both the data in Table 4, and Table 2 described above). We can draw two conclusions from this fact. First, it shows that vicinity matters - groups who are able to observe the local environment distinguish more details about its elements, whereas for more distant respondents those elements were pretty much the same. One can also conclude that managing the natural environment and its hazards is a very local issue, even though mitigating unfavourable changes requires the coordinated activity of a much bigger area (e.g. the whole water basin). Second, the results show that even the knowledge of the (more, not better, informed) activists and the lake's neighbours is far from the hydrological knowledge about the sensitivity of the lakes and its determinants. Indeed, more information - but not necessarily true information
- is possessed by the more educated group of activists, which gives an ambivalent input for the verification of $\mathrm{H} 2 \mathrm{a}$.

An analysis of the "don't know" answers in the defined groups confirms these findings. Not surprisingly, activists used this answer less frequently than pupils, and respondents living near the lakes less frequently than those living further away (differences between the means are statistically important, as in the " $t$ " test $p<0.05)$.

We have also checked to what extent the respondents notice that changes in the lakes and threats depend on meteorological conditions. We asked about four possible factors influencing the condition of the lakes: meteorological conditions, human activity, rivers supplying the lakes, and environmental protection policies. As we can see (Table 5), meteorological conditions are a much less popular explanation than human activity. The pattern is most clear for Charzykowskie Lake, which is in fact exposed to stronger human impact than the lakes located in the National Park.

Splitting the sample into groups proved statistically significant only for Charzykowskie Lake. It is surprising that the group of activists also underestimates the importance of meteorological factors, in the same way as the respondents living close to the lakes.

Even though differences between other groups are not statistically significant (due to the small $N$ ), they seem interesting enough to mention. The only group who perceives meteorological conditions as being very influential (and thus spoke against the confirmation of $\mathrm{H} 2$ ) are employees of local environmental NGOs. They even distinguish properly between the less sensitiveto-climate Charzykowskie Lake ( $11 \%$ of answers indicated meteorological conditions as a threat) and the more sensitive Gacno and Ostrowite lakes (46\% and $30 \%$, respectively). 
A similar pattern of answers was observed among the respondents from the oldest group - they are reluctant to see this risk for Charzykowskie and Ostrowite lakes, but are very willing to see it in the case of the Gacno lakes. In doing so, both groups are closest to the hydrological results.

Representatives of NGOs have enough information due to the type of activities they undertake (the percentage of "don't know" answers was very low in this group). The fact that elderly people also have greater knowledge might be explained by the fact that they base their judgments on a longer period of observations.

A crucial aspect of this study is our ability to compare local actors' perspectives against our hydrological findings. According to the hydrological scrutiny, Charzykowskie is the least vulnerable to extreme weather conditions and climate changes, whereas Gacno and Ostrowite lakes are very sensitive to those factors. Our respondents answered exactly opposite. The most evident mismatch between the perception and the hydrological facts was noted for students and respondents living further away from the studied lakes.

All these analyses suggest that the answers from all groups of respondents resulted from a lack of detailed knowledge (unfortunately also in the group who could serve as local activists), rather than from scientifically-based information. The study makes it clear that people do notice threats caused by human activity, while they overlook climate influence.

Sources of information and variation in the lakes' perception

The study shows that, for the majority of respondents, the most important source of information about the condition of the lakes was their own observations (Fig. 4). This would explain why respondents living further away from the lakes often had difficulties answering the questions, and why the eldest respondents were close to the hydrological findings.

It also supports our other findings on differences in the perception of the lakes. The lakes located in the National Park (with very limited access for the community), the Gacno lakes and Ostrowite Lake, are in general, perceived in a similar way; whereas Charzykowskie Lake (the one used for leisure, water sports and secondary housing) appears to be perceived very differently. The perception is determined by accessibility (location in or out of the National Park) and the use of the lake because, according to the respondents, the human impact poses a bigger threat to the lakes than meteorological conditions. Charzykowskie Lake, not being covered by the National Park, is exposed to human use. We have discovered a common belief that goes like this: if the lake is not protected by the National Park, it is endangered (by human activities) and its condition is definitely poor as it is extensively used by inhabitants and tourists. The lakes included in the Park are one, protected and two, apparently valuable enough to be protected (meaning that they are in good ecological condition).

What is more, frequent "don't know" answers in case of Ostrowite Lake and the Gacno Lakes indicate that people do not know much about the lakes "hidden" in the National Park. This poses yet another proof for claiming that knowledge is based mainly on personal observation - things difficult to observe remain unknown.

Other sources of information on the local natural environment are friends and family, which can be treated as a source of indirect observation. Other different sources are the Internet and local media, which appear in the third and fourth position. Yet, looking at the percentages one would expect higher values (especially in case of the Internet, where all institutions involved in environmental management have well-developed and updated websites). This indicates, on the one hand, the important role of local press and NGOs in providing knowledge, and on the other;

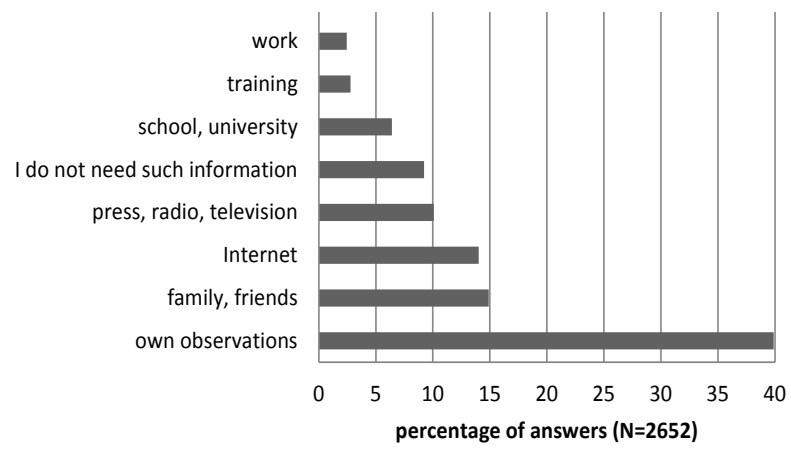

Figure 4. Sources of information about the lakes

a need to popularise those sources of knowledge. It is worrisome that in a sample dominated by pupils and students only $9 \%$ of answers indicated professional sources of information like school and training! There is definitely a lot to be done in terms of improving knowledge transmission in educational institutions. Climate change and climate policies should become a more visible part of teaching programmes. Another problematic issue is that almost $10 \%$ of the respondents agreed with the statement: "I do not need such information and I do not look for it".

It is interesting that the assessment on the awareness of inhabitants of the condition of the lakes does not depend on the age of respondents, their place of residence, or affiliation with the group of activists or students (pupils). The ANOVA test shows that the only variable significantly differentiating the responses is their link to environmental issues, that is, there are significant differences between the answers of students and professionals in sectors related to environmental protection and water management (in Bonferroni's test $p=0.025$; the difference between the means is 0.164 ).

It is symptomatic that only $23 \%$ of the respondents think that inhabitants are well-informed about the condition and the threats posed to the lakes in the study. Interestingly, it is not difficult language that is to blame (only $16.7 \%$ of the respondents), but the ways in which the information is published $(60.3 \%$ think they are inappropriate).

Most respondents admitted that more information would contribute to the better protection of the lakes $(69 \%)$, but a further $31 \%$ did not share that view. Most of the latter group (19\% of the whole sample) think that everyone should know what to do to take care of the environment; only $10 \%$ think that protection of the lakes is a matter for special services that need specialised information.

The results are coherent with the findings from our other project, PolCitClim (Swianiewicz, Szmigiel-Rawska 2015). In a survey of Polish municipalities only $20 \%$ of respondents declared a recent participation in conferences or seminars related to climate change and climate policies, and only $16 \%$ knew of another person from the municipal hall who participated in such training. In the same study carried out in Norwegian municipalities, the figures were more than two times higher (50\% and $58 \%$ respectively). Indeed, professional training on meteorological conditions and climate policies are very underdeveloped in Poland.

\section{Verification of hypothesis and wider discussion}

The sociological study has provided an important insight into the issue of local natural resources management. The survey proved that the local stakeholders' perception of the conditions of the studied lakes significantly differs from the objective picture resulting from the hydrological research. It is hard to analyse the respondents' assessment in terms of hydrological knowledge. 
The new extreme meteorological events, resulting from climate changes, are not clearly perceived by inhabitants, regardless of the professional group they belong to. All the distinguished groups perceive Charzykowskie Lake as the most sensitive, which is contrary to the hydrological findings. This shows the first hypothesis $(\mathrm{H} 1)$ to be false - Charzykowskie Lake has a low contemporary sensitivity to weather conditions, but due to the high level of human pressure it is seen as the most vulnerable. Considering only the human impact, local actors overlooked meteorological conditions, especially that their impact on Charzykowskie Lake is mild and often varied over time, and thus hard to observe. This and other results confirmed the second hypothesis $(\mathrm{H} 2)$ - the links between the condition of the lakes and meteorological factors are to a great degree, overlooked. This is coherent with the fact that the assessment of the lake exposed to human activity (Charzykowskie Lake) was always poorer when compared to the lakes protected by the structures of the National Park. The only groups whose answers were more in line with hydrological knowledge were members of local NGOs and elderly people, who gave the only confirmation of the second part of the second hypothesis ( $\mathrm{H} 2 \mathrm{a})$. Very surprisingly, local administrative staff who deal with the natural environment in municipalities appeared less educated on this issue.

In drawing conclusions from these facts one should be very careful, as the differences between the groups were often statistically insignificant and, in general, the individual features of respondents did not differentiate the answers as strongly as was expected based on the literature (Burton and Kates 1964; Cutter et al. 1992; Lindell and Prater 2002; Peacock et al. 2005). One of the possible explanations for the identified status quo is the fact that various educational environmental initiatives in the Tuchola Region tend to focus on human pressure rather than on climate change and its meteorological implications.

Moreover, one has to remember that questions about the threats posed to the lakes by meteorological impact are difficult, as the scenarios related to climate change and its meteorological consequences are uncertain. Yet, the answers show that most of the activists that are interested in local natural resources, the professionals managing those resources, as well as young people, are not aware of the relationship between weather and the condition of the lakes (this confirms $\mathrm{H} 2$ ). As a result, one should not expect them to press for the local climate change adaptation or mitigation policies in the future.

These findings are coherent with declarations about the information they had and its sources. The local community was assessed as having limited access to information on environmental issues. Even more disquieting is the fact that one in ten respondents declared no interest in such issues.

The authors' findings, indicating a low level of knowledge about the natural environment, also speak against expecting the local community to develop proper management in regards to environmental threats in the process of local participatory governance. They simply do not see the problem and are not interested. Local governance becomes dysfunctional if some of the groups of stakeholders are excluded from common undertakings because of a low level or lack of ecological awareness.

A certain consolation is the fact that respondents who benefit from the lakes (services for tourists, other types of businesses that benefit from the lakes' assets) and those who live close enough to observe the lakes are more precise in their opinions about the ecological conditions.
The lack of reaction to the survey from respondents from municipalities located on the periphery of the catchment should be seen by local managers as a warning. These municipalities also contribute to changes in the ecological conditions of the lakes, and they still seem not to care. A passive approach and lack of interest call for regional government intervention and stronger involvement in managing the natural environment, including on a sub-regional and local scale (Corraliza and Berenguer 2000).

The most severe problem with communication that respondents diagnosed was the inadequate channels of information distribution. In this context, a big challenge for local and regional public authorities, and for special environmental services is to design efficient ways of communicating with the public (Brower et al. 1983; James et al. 2011). Local media and the Internet could play a more important role in facilitating information flow than it is at the moment. It seems that, although the information is available (especially on the websites of the various agencies dealing with climate research and policies), the awareness of where and how it can be acquired is insufficient. This might also be explained by the low level of interest in environmental issues among Internet users. Thus, the efforts of managers should be focused not only on the "production of information that can be used" but also on generating the demand for information, as well as on facilitation of the flow of information to make sure that those looking for information have easy access. This is especially true, as the mechanisms of perception of weather phenomenon speak against noticing slow, incremental changes (as in the case of Charzykowskie Lake).

Effective environmental management requires the coordination of activities at different tiers of governance, and public involvement and support (Eckerberg and Joas 2004; Lempert et al. 2004). In the process of mutual learning, groups of stakeholders with specific powers and responsibilities should prepare themselves for different scenarios related to climate change. Close cooperation is needed (Cash et al. 2006). Intermediate organizations like NGOs can facilitate cooperation among different stakeholders (Cox et al. 2010).

Communicating about environmental threats serves many important purposes. It can be used either as a tool to provide information, to explain and warn or to encourage collective partnership approaches to decision-making through greater public participation in the threat management process (Calow 1998; Gondo 2011). The results of the study show that, even if there is adequate knowledge about the environment, it will not be translated into practical undertakings and actions unless there is an effective mechanism for information sharing.

\section{Acknowledgments}

The article includes the results of studies carried out in Poland at the Institute of Meteorology and Water Management - National Research Institute (IMGW-PIB) with the cooperation of the Faculty of Geography and Regional Studies, University of Warsaw (WGSR UW). This study was conducted within the framework of the EULAKES project, funded by the Central Europe Program (project No. 2CE243P3), financed by the European Regional Development Fund (ERDF) and scientific work financed from the funds for science in 2011-2013 granted in order to implement an international co-funded project. The Authors are grateful to the authorities of local government bodies, the Zaborski Landscape Park, and the Tuchola Forest National Park, for their cooperation, and also to all those who contributed to the distribution and collection of the questionnaires. 


\section{References}

Axelrod, LJ \& Lehman, DR 1993, 'Responding to environmental concerns: What factors guide individual action?', Journal of Environmental Psychology, no. 13, pp. 149-159.

Biesbröek, RG, Swart, RJ \& van der Knaap, WGM 2009, 'The mitigation-adaptation dichotomy and the role of spatial planning', Habitat International, no. 33 pp. 230-237.

Brower, SK, Dockett, \& Taylor, RB 1983, 'Residents perceptions of territorial features and perceived local threat', Environment and Behavior, vol. 15 no. 4, pp. 419-437. DOI: $10.1177 / 0013916583154002$.

Bulkeley, H \& Kern, K 2006, 'Local government and the governing of climate change in Germany and the UK', Urban Studies, vol. 43, no. 12, pp. 2237-2259.

Burton, I \& Kates, R 1964, 'The perception of natural hazards in resource management', Natural Resources Journal, vol. 3, no. 3, pp. 412-441.

Calow, P 1998, Handbook of environmental risk assessment and management, Oxford, Blackwell Science.

Carmi, N \& Bartal, E 2014, 'Perception of environmental threat in the shadow of war the effect of future orientation', Human and Ecological RiskAssessment: An International Journal, vol. 20, issue 3, pp. 872-886. DOI: 10.1080/10807039.2013.798217.

Cash, DW, Adger, WN, Berkes, F, Garden, P, Lebel, L, Olsson, P, Pritchard, L, \& Young, O 2006, 'Scale and cross-scale dynamics: governance and information in a multilevel world', Ecology and Society, vol. 11, no. 2, pp. 8-19.

Corraliza, JA \& Berenguer, J 2000, 'Environmental values, beliefs, and actions: A situational approach', Environment and Behavior, no. 32, pp. 832-848.

Cox, M, Arnold, G \& Tomás, SV 2010, 'A review of design principles for community-based Natural Resource Management', Ecology and Society, vol. 15, no. 4, pp. 38-56.

Cutter, SL, Tiefenbacher, J \& Solecki, WD 1992, 'En-gendered fears: femininity and technological risk perception', Industrial Crisis Quarterly, vol. 6, no. 1, pp. 5-22.

Eckerberg, K \& Joas, M 2004, 'Multi-level environmental governance: a concept under stress?', Local Environment vol. 9, issue 5, pp. 405-412.

European Environment Agency (ed.) 2008, 'Impacts of Europe's changing climate - 2008 indicator-based assessment', EEA Report 4/2008, EEA, Brussels.

Feldman, DL \& Ingram, HM 2009, 'Making science useful to decision makers: Climate forecasts. Water management and knowledge networks', Weather, Climate, and Society, no. 1 , pp. 9-21. DOI: $10.1175 / 2009$ WCAS 1007.1

Gendźwiłł, A 2016, 'Zdecentralizowana adaptacja? Opinie władz lokalnych o zmianach klimatu i lokalnej polityce adaptacji do zmian klimatycznych', paper elaborated within Polcitclim project, in publishing process.

George, G (ed.) 2010, The impact of climate change on European lakes, Springer Dordrecht, Heidelberg, London, New York,

Gondo, T 2011, 'Adaptive co-management of natural resources: A solution or problem?', Journal of Human Ecology, vol. 33, no.2 pp. 119-131.

Granberg, M \& Elander, I 2007, 'Local governance and climate change: reflections on the Swedish experience', Local Environment, vol. 12, no. 5, pp. 537-548.

Grimble, R \& Wellard, K 1997, 'Stakeholder methodologies in natural resource management: a review of concepts, contexts, experiences and opportunities, Agricultural Systems, no. 55, pp. 173-193.

Hanssen, GS, Mydske, PK \& Dahle, E 2013, 'Multi-level coordination of climate change adaptation: by national hierarchical steering or by regional network governance?'
Local Environment: The International Journal of Justice and Sustainability, vol. 18, no. 8, pp. 869-887. DOI: 10.1080/13549839.2012.738657.

Hoppe, T, van den Berg, M \& Coenen, F 2014, 'Reflections on the uptake of climate change policies by local governments: facing the challenges of mitigation and adaptation, Energy', Sustainability and Society, vol. 4, no. 8, pp. 1-16.

IPCC 2012, 'Managing the risks of extreme events and disasters to advance climate change adaptation' A Special Report of Working Groups I and II of the Intergovernmental Panel on Climate Change, First published 2012. Available from: $<$ http://www.ipcc.ch/pdf/special-reports/srex/SREX_Full_ Report.pdf>. [1 February 2013]

Jackson, T \& Lynch, W 2011, 'Public sector responses to climate change: evaluating the role of Scottish Local Government in implementing the climate change (Scotland) Act 2009', Research and Evaluation Commonwealth Journal of Local Governance, no. 8/9. Available from: <http://epress.lib.uts. edu.au/ojs/index.php/cjlg>. [28 July 2014]

James, RT, Havens, KE, McCormick, P, Jones, B \& Ford, C 2011 , 'Water quality trends in shallow South Florida Lakes and assessment of regional versus local forcing functions', Critical Reviews in Environmental Science and Technology, vol. 41, no. 1, pp. 576-607. DOI: 10.1080/10643389.2010.530581

John, P 2001, Local governance in Western Europe, Sage, London.

Johnson, TE \& Weaver, ChP 2009, 'Framework for assessing climate change impacts on water and watershed systems', Environmental Management, no. 43, pp. 118-134. DOI: 10.1007/s00267-008-9205-4

Kates, RW, 1971, 'Natural hazard in human ecological perspective: hypotheses and models', Economic Geography, vol. 47, no. 3 , pp. 438-451.

Kutics, K 2012, 'Impacts of climate change scenarios part: Lake Balaton' in Report 4.4.1 EULAKES Project Ref. No. 2CE243P3, Lake Balaton Development Council. Hungary.

Lackowska, M \& Swianiewicz, P 2016, 'Czynniki warunkujące postawy i działania samorządów gminnych w Polsce w zakresie łagodzenia i adaptacji do zmian klimatycznych', paper elaborated within Polcitclim project, in publishing process.

Langford, I, Georgiou, S, Bateman, I, Day, R \& Turner, R 2000, 'Public perceptions of health risks from polluted coastal bathing waters: a mixed methodological analysis using cultural theory', Risk Analysis, vol. 20, no. 5, pp. 691-704. DOI: 10.1111/0272-4332.205062.

Lempert, R, Nakicenovic, N, Sarewitz, D \& Schlesinger, M 2004, 'Characterizing climate-change uncertainties for decisionmakers', Climatic Change, no. 65, pp. 1-9.

Lindell, MK \& Prater, CS 2002, 'Risk area residents perceptions and adoption of seismic hazard adjustments', Journal of Applied Social Psychology, vol. 32, no. 11, pp. 23772392. DOI: 10.1111/j.1559-1816.2002.tb01868.x

Lynch, AJ 2011, 'The usefulness of a threat and disturbance categorization developed for Queensland Wetlands to environmental management, Monitoring and evaluation', Environmental Management, no. 47, pp. 40-55. DOI: 10.1007/s00267-010-9562-7

Mazur, S (ed.) 2015, Współzarządzanie publiczne Scholar, Warszawa.

Nowicka, B \& Lenartowicz, M 2004, 'Variability in the process of the lake feeding by the groundwater (case study of small basin in South Pomeranian Lake District)', Progress in surface and subsurface water studies at the plot and small 
basin scale. IHP VI Technical Documents in Hydrology, vol. 77, UNESCO, Paris, pp. 15-21.

Nowicka, B 2006, 'Hydrogeology and hydrology of Lake Ostrowite' in Lakes and mires of Bory Tucholskie National Park, eds G Kowalewski \& K Milecka, Oficyna Wyd. FOREST, Park Narodowy „Bory Tucholskie” Charzykowy, pp. 63-73.

Nowicka, B 2009, 'Ocena zróżnicowania ekstremalnie wysokich przepływów wybranych rzek polskich, Prace i St. Geogr. UW, no. 43, pp. 11-24.

Nowicka, B \& Bałandin, M 2012, 'Impact of climate change on water balance of a large flow-through lake (case study Lake Charzykowskie)' IMPACT International Conference on Managing Protected Areas under Climate Change. Available from: <http://www.habit-change.eu/fileadmin/ Dateisammlung/files/impact/pdf_sessions/monitoring/ Nowicka_Balandin_presentation.pdf $>$.

Nowicka, B, Bałandin, M, Grześkowiak A \& Nadolna, A 2012, 'Impacts of climate change scenarios part: Charzykowskie Lake' in Report 4.4.1, EULAKES Project Ref. No. 2CE243P3, IMGW-PIB, Warsaw, Poland.

Nowicka, B, Bałandin, M \& Nadolna, A 2016, 'Lakes sensitivity to climatic stress-a hydrological assessment', paper elaborated within EULAKES project Ref. No. 2CE243P3, in publishing process.

Orderud, GI \& Winsvold, M 2012, 'The role of learning and knowledge in adapting to climate change: a case study of Norwegian municipalities' International Journal of Environmental Studies, vol. 69(6), pp. 946-961.

Peacock, WG, Brody, SD \& Highfield, W 2005, 'Hurricane risk perceptions among Florida's single family homeowners', Landscape and Urban Planning, vol. 73, no. 2-3, pp. 120-135. DOI: 10.1016/j.landurbplan.2004.11.004.

Rannow, S, Loïbl, W, Grieving, S, Gruehn, D \& Meyer, BC 2010, 'Potential impacts of climate change in Germany - Identifying regional priorities for adaptation activities in spatial planning', Landscape Urban Planning, no. 98, pp. 160-171.

Reed, M, Graves, A, Dandy, N, Posthumus, H, Hubacek, K, Morris, J, Prell, C, Quinn, C \& Stringer, L 2009, 'Who's in and why? A typology of stakeholder analysis methods for Natural Resource Management', Journal of Environmental Management, no. 90, pp. 1933-1949.

Romanelli, A, Massone, HE \& Escalnte, AH 2011, 'Stakeholder analysis and social-biophysical interdependencies for common pool resource management: La Brava Wetland (Argentina) as a case study', Environmental Management, no. 48, pp. 462-474. DOI: 10.1007/s00267-011-9698-0.

Schröter, D 2005, 'Vulnerability to changes in ecosystem services', CID Graduate Student and Postdoctoral Fellow Working Paper, no. 10, Cambridge, MA: Science, Environment and Development Group, Center for International Development, Harvard University.
Shaw, K \& Theobald, K 2011, 'Resilient local government and climate change interventions in the UK', Local Environment, vol. 16 , no.1, pp. 1-15.

Sighel, AM 2012, 'Impacts of climate change scenarios part: Lake Garda' in Report 4.4.1 EULAKES Project Ref. No. 2CE243P3, APPA, Environment Protection Agency of the Province of Trento, Italy.

Slovic, P, Fischhoff, B \& Lichtenstein, S 1982,. 'Why study risk perception?', Risk Analysis, vol. 2, no. 2, pp. 83-93. DOI: 10.1111/j.1539-6924.1982.tb01369.x

Soja, AM, Weiss, S, Zukrigi, W \& Soja, G 2012, 'Impacts of climate change scenarios part: Lake Neusiedl' in Report 4.4.1 EULAKES Project Ref. No. 2CE243P3, AIT, Naturschutzbund Burgenland, Wiena, Austria.

Storbjörk, S 2007, 'Governing climate adaptation in the local arena: challenges of risk management and planning in Sweden', Local Enviroment, vol. 12, no. 5, pp. 457-469.

Sulzmann, EW, Poiani, KA \& Kittel, TGF 1995, Modeling humaninduced climate change: a summary for environmental managers, Environmental Management, vol. 19, no. 2, pp. 197-224.

Swianiewicz, P, \& Szmigiel-Rawska, K 2015, 'Nie wierzymy w zmiany klimatyczne', Wspólnota, no. 9, pp. 66-68.

Szmigiel-Rawska, K 2016, 'Mechanizmy polityki klimatycznej polskich samorządów', paper elaborated within Polcitclim project in publishing process.

Tierney, K, Lindell, M \& Perry, R 2001, Facing the unexpected: Disaster preparedness and response in the United States, Washington, DC, Joseph Henry Press.

Varvasovszky, Z \& Brugha, R 2000,'How to do (or not to do) a stakeholder analysis', Health Policy and Planning, no. 15, pp. 338-345.

Wong, KK \& Zhao, X 2001, 'Living with flood: victim's perceptions in Beijiang, Guangdong, China', Area, vol. 33, no. 3, pp. 190-201.

'Wpływ zmian klimatu na środowisko gospodarkę i społeczeństwo', 14-15 March 2012, IMGW-PIB, Warsaw.

Zdanowski, B, Stawecki K, Prusik, S \& Hutorowicz, J 2004, 'Fizykochemiczne właściwości wód' in Ekosystemy wodne Parku Narodowego "Bory Tucholskie", eds B Zdanowski, A Hutorowicz, \& W Białokoz, Olsztyn, Wydawnictwo Instytut Rybactwa Śródlądowego Olsztyn pp. 17-32. 